Dinamika Sosial Budaya, Vol 21, No. 2, Desember 2019, pp 138-151

p-ISSN: 1410-9859\& e-ISSN: 2580-8524

http://journals.usm.ac.id/index.php/jdsb

\title{
PENGGUNAAN UNSUR-UNSUR SENI PERTUNJUKKAN KETHOPRAK DALAM IKLAN TVC DJARUM 76 SERI JIN SEBAGAI STRATEGI BRANDING PRODUK
}

\author{
Yoga Rarasto Putra \\ Fakultas Teknik, Jurusan Desain Komunikasi Visual Institut Teknologi dan Bisnis Ahmad Dahlan Jakarta \\ yogararastoputra@gmail.com \\ Andri Meiriki \\ Fakultas Ekonomi Digital, Jurusan Manajemen Institut Teknologi dan Bisnis Ahmad Dahlan Jakarta \\ meirikiandri@gmail.com \\ Firdaus Azwar Ersyad \\ Fakultas Teknologi Informasi dan Komunikasi, Jurusan Ilmu Komunikasi Universitas Semarang \\ Firdaus.azwar@usm.ac.id
}

\begin{abstract}
ABSTRAK
Kehadiran iklan televisi merupakan salah satu cara bagi produsen untuk memperkenalkan dan menjual produknya ke masyarakat. Regulasi mengenai iklan khususnya produk rokok dan tembakau mendorong produsen agar lebih kreatif dalam memperkenalkan produknya pada khalayak. Akibatnya, kreatifitas di dalam iklan rokok bertujuan mengangkat citra produk sehingga tidak menampilkan produk secara langsung. Penelitian ini berawal dari ketertarikan terhadap visualisasi iklan-iklan Djarum 76 seri Jin Jawa yang memiliki ciri khas tersendiri dibandingkan produk rokok lainnya. Tampilannya yang lucu dan menghibur tidak menampakkan bahwa pengiklan sedang menjual produk. Penampilan iklan secara sinematik maupun naratif terlihat menggunakan kaidah-kaidah seni pertunjukkan kethoprak. Metode penelitian yang digunakan adalah kualitatif deskriptif dan teori yang digunakan untuk menganalisis tanda adalah semiotika Roland Barthes. Melalui analisis tersebut, diperoleh kesimpulan yang menjelaskan bagaimana cara iklan Djarum 76 membangun konstruksi brand image dalam benak masyarakat serta konsumennya.
\end{abstract}

\section{Kata Kunci : iklan Djarum 76, hiburan, kethoprak, kritik sosial, branding}

\section{PENDAHULUAN}

Indonesia adalah salah satu negara dengan konsumsi rokok terbesar. Dalam kehidupan seharihari kita dapat menemukan perokok di berbagai tempat dan dari berbagai kalangan strata, ekonomi, maupun usia. "Indonesia surga bagi industri rokok, tapi neraka buat rakyatnya," ucap Hasbullah Thabrany, Ketua Pusat Kajian Ekonomi dan Kebijakan Kesehatan Universitas Indonesia (Yoga, Tesis, 2016: 1). Harga rokok di Indonesia masih sangat murah jika dibandingkan negara lain, termasuk negara tetangga, seperti Singapura, Malaysia, Thailand, dan Laos. Di Singapura misalnya, harga rokok jika dirupiahkan sekitar Sembilan puluh ribuan hingga seratus ribuan, begitu pula di Malaysia. Di Indonesia, berbagai jenis rokok banyak dijual dengan harga yang lebih murah. Harga yang ditawarkan mulai belasan ribu hingga puluhan ribu rupiah saja. Bea cukai tembakau yang relatif rendah hingga peminat rokok yang sangat tinggi di Indonesia membuat industri ini tumbuh kian subur. Hal ini tentu saja memberi ruang yang sangat luas terhadap para produsen kecil dan besar hingga para pengecer.

Di tengah persaingan yang ketat pada industri rokok, para produsen besar menjalankan berbagai strategi bisnis untuk mempertahankan eksistensinya di tengah masyarakat. Persainganpersaingan tersebut diantaranya dalam hal; harga, diversifikasi produk, diferensiasi target market, hingga marketing. Strategi-strategi yang dijalankan cukup beragam guna menanamkan positioning product mereka dalam klasifikasi dan kelas sosial masyarakat.

Iklan TVC atau iklan televisi adalah salah satu media pemasaran atau marketing yang paling populer digunakan oleh para pengusaha besar industri rokok. Menurut Ezki Suyanto dalam (Yoga, Tesis, 2016: 1), Iklan rokok telah diketahui merupakan daya tarik yang baik, terutama bagi remaja dan anak-anak untuk mencoba rokok. Daya tarik yang kuat ini mampu menimbulkan semangat, daya Tarik, hingga mengkonstruksikan lifestyle bagi kelompok-kelompok tertentu yang membedakan antar golongan lapisan di masyarakat. Pembagian golongan atau kelompok biasanya didasarkan pada jenis rokok, harga, cita rasa dan selera.

Iklan rokok diatur dalam edaran yang dikeluarkan oleh Komisi Penyiaran Indonesia (http://www.kpi.go.id/index.php/id/edaran-dan- 
sanksi/31912-edaran-untuk-lembaga-penyiaranperihal-iklan-rokok?detail $3=4184 \&$ detail $5=5366$, akses 15 Juli 2019), disebutkan bahwa UndangUndang No.32 tahun 2002 tentang Penyiaran (UU Penyiaran) Pasal 46 ayat (3) huruf c melarang iklan niaga melakukan promosi rokok yang memperagakan wujud rokok. Selain itu, Standar Program Siaran (SPS) Pasal 58 ayat (4) huruf c telah melarang promosi rokok yang memperagakan wujud rokok. Akibat regulasi ini, maka iklan rokok ditampilkan dengan sangat berbeda dari iklan-iklan produk lainnya. Iklan rokok di televisi cenderung menampilkan sesuatu yang bias dan tidak terkait dengan produk yang dijual. Karena iklan rokok tidak menampilkan produknya dengan jelas, maka makna iklan harus dimunculkan secara implisit. Sedangkan untuk iklan-iklan produk lain, biasanya pesan ditayangkan secara vulgar (jelas) dan bersifat persuasif. Aturan yang berbeda tersebut membuat Iklan ini terbilang sangat canggih dan shopisticated dalam penayangannya. Inilah yang menyebabkan para kreator serta pembuat iklan rokok dituntut lebih kreatif dalam memvisualisasikan produk rokok agar tetap dapat diterima masyarakat dan tidak melanggar undangundang penyiaran serta peraturan yang berlaku. Konsep yang bias dari iklan rokok tersebut juga berlaku terhadap media-media lainnya. Terkadang dalam keseharian, dapat kita lihat bagaimana nama-nama atau brand rokok menghiasi berbagai event perlombaan dan panggung musik baik di Perkampungan atau Perkotaan.

Di tengah pesatnya persaingan industri rokok, pihak PT. Djarum mengeluarkan varian produk kretek bernama Djarum 76 yang memiliki ciri khas tradisional. Dalam pemasarannya, Djarum 76 banyak membuat iklan-iklan yang mengangkat tema-tema merakyat, tradisional, unik dan mengandung unsur komedi. Tampilan iklan yang unik tersebut ternyata mampu bertahan dan menjaga eksistensi produk hingga kini. Iklan Djarum 76 seri Jin Jawa adalah salah satu yang fenomenal karena konsep tersebut merupakan konsep yang mampu bertahan paling lama, setidaknya hingga kini (2019) sejak pertama disiarkan pada 2009. Tampilan iklan Djarum 76 seri Jin Jawa yang menghibur terlihat sangat kental dengan nuansa budaya Jawa serta panggung hiburan kethoprak. Akan tetapi, iklan sebagai media audio visual memiliki peran yang sangat penting dalam upaya transmisi pesan sekaligus sebagai strategi branding dari produk yang ditawarkan. Melihat kentalnya kebudayaan rakyat tradisional dan nuansa khas pertunjukkan kethoprak dalam iklan, maka penelitian ini mengambil judul "Penggunaan Unsur-Unsur Seni Pertunjukkan Kethoprak Dalam Iklan TVC Djarum 76 Seri Jin Sebagai Strategi Branding Produk". Dalam penelitian ini, penulis akan melihat bagaimanakah iklan Djarum 76, khususnya seri Jin Jawa ditampilkan lalu ciri khas apa yang paling menonjol dalam iklan-iklannya? Kemudian, tanda apa saja yang dianggap sangat menonjol dan merupakan ciri khas pertunjukkan kethoprak? Terakhir, adakah relevansi antara penggunaan tampilan-tampilan tersebut dengan positioning serta branding product Djarum 76 di masyarakat?

Melalui penelitian ini, diharapkan dapat menjadi referensi bagi Pengiklan dan pihak Korporasi tentang bagaimana membuat iklan rokok yang efektif dan unik. Bagi para Peneliti lainnya, diharapkan penelitian ini mampu memberikan referensi tambahan tentang bagaimana meneliti tanda-tanda visual dalam iklan produk rokok.

\section{TINJAUAN PUSTAKA}

\subsection{Teori Periklanan dan TV Commerce}

Definisi periklanan yaitu bentuk komunikasi komersil dan non-personal tentang sebuah organisasi dan produk-produknya yang ditransmisikan ke suatu khalayak target melalui media massa seperti; televisi, radio, koran, majalah, direct mail, reklame, atau kendaraan umum (Lee dan Johnson, terj., Munandar dan Priatna, 2011: 3). Proses transmisi merupakan cara pengiriman pesan tentang promosi produk yang ditawarkan. Pengirim pesan adalah penjual produk, sedangkan penerima pesan adalah khalayak ramai yang menjadi sasaran iklan (Hoed, 2001: 95). Pesan yang disampaikan menurut Supriyanto terdiri dari berbagai jenis, salah satunya adalah promosi yang dikategorikan menjadi dua yaitu above the line promotion (ATL) dan below the line promotion (BTL). ATL merupakan kegiatan promosi menggunakan media sebagai perantara, seperti TV, radio, internet, dan media-media lain. BTL adalah kegiatan promosi tanpa perantara, biasanya produk ditawarkan langsung oleh penjual atau agensi-agensi seperti SPG rokok, mobil, motor, atau lainnya (Supriyanto, 2008: 18 - 19). Promosi adalah bagian yang tak terpisahkan dari marketing atau pemasaran. Melalui promosi, branding atau citra tentang produk bisa lebih efektif ditransmisikan kepada khalayak.

Iklan pada dasarnya merupakan sebuah simulasi tentang realitas buatan (artifisial) yang sengaja diciptakan sebagai keadaan atau dikondisikan sebagai realitas bentuk baru. Keadaan ini memungkinkan terjadinya sebuah realitas yang tercampur dengan mitos-mitos yang ada hingga memunculkan kondisi buatan dan disebut sebagai 
hiperrealitas atau posrealitas. Menurut Baudrillard, hiperrealitas dimunculkan oleh simulasi dan tidak melalui referensi representasi dari luar dirinya. Simulasi menjadikan dirinya sendiri sebagai referensi (Piliang, 2009: 59).

Iklan merupakan media yang dikendalikan oleh dinamika pasar dan pemasaran (marketing). Di dalam ilmu marketing terdapat sebuah rumus baku yang dikenal sebagai AIDA. AIDA merupakan sebuah rangkaian proses yang dilalui oleh pemirsa iklan untuk kemudian menjadi seorang pembeli produk. AIDA merupakan singkatan yang merupakan rumusan dari:

1. Tahap menarik perhatian (Attention).

2. Tahap menimbulkan ketertarikan (Interest).

3. Tahap memunculkan hasrat/ minat (Desire).

4. Tahap merangsang untuk memunculkan respon atau membeli (Action).

Tahap-tahap tersebut merupakan rumus penting yang digunakan untuk mempengaruhi respon pasar terhadap iklan (Djamal \& Fachruddin, 2011: 71). Konsep AIDA pada dasarnya hanya menyentuh pada aspek-aspek psikologis calon pembeli produk melalui iklan yang ditampilkan. Dewasa ini, konsep AIDA telah ditambahkan "S" menjadi AIDA(S). Huruf "S" merupakan satisfaction atau kepuasan (Kuncara, (2012). http://adabisnis.com/seberapa-efektifkah-iklananda/, akses 30 Agustus 2015).

\subsection{Teori Semiotika}

Semiotika merupakan bidang keilmuan yang mengkaji seputar hubungan antara tanda dan makna yang ada di dunia ini. Secara etimologi, Kata "semiotika" itu sendiri berasal dari bahasa Yunani, semeion yang berarti "tanda" atau "seme" yang berarti "penafsir tanda". Semiotika berakar dari studi klasik dan skolastik atas seni logika, retorika, dan poetika (Sobur, 2009: 16).

Saat ini terdapat dua pendekatan semiotika yang populer yaitu semiotika komunikasi yang sering dipraktikkan oleh Charles Sanders Pierce dan semiotika signifikasi yang dipopulerkan oleh Ferdinand de Saussure. Saussure dikenal melalui pandangannya tentang tradisi linguistik beserta konsep dikotomisnya. Dikotomi-dikotomi dalam linguistik bagi Saussure adalah mengenai relasi dan perbedaan konsep sinkronik-diakronik bahasa, langue-parole, sintagmatik-paradigmatik, hingga penanda (signifier) dan petanda (signified) (Budiman, 2011: 24).

Roland Barthes adalah salah satu tokoh semiotika yang paling sering mempraktikkan konsep-konsep semiotika struktural Saussure yang kemudian dikembangkan kembali olehnya. Barthes melihat persoalan yang dihadapi semiologi Saussurean akibat penekanan pada analisis linguistik sebagai sistem bahasa, sehingga Barthes perlu menekankan secara lebih luas dalam mythology.

Menurut Barthes, konsep langue dan parole dalam pemikiran saussure dalam praktiknya adalah efektifitas bahasa yang hanya berjalan sebagai langue. Bagi Barthes, langue dalam perspektif linguistik adalah sistem sosial yang otonom melalui konvensi. Parole menurut Barthes merupakan suatu tindakan individual yang merupakan seleksi dan aktualisasi. Dari istilah tersebut, maka dapat disimpulkan bahwa masingmasing unsur tersebut saling berhubungan agar suatu bahasa memiliki makna sepenuhnya. Tidak ada langue tanpa parole, dan tidak ada parole yang berada diluar langue (Sudjiman \& Zoest, 1992: 80 $-82)$.

Dalam proses signifikasi, Roland Barthes menawarkan dua tataran/ lapisan signifikasi yang lebih kompleks ketimbang Saussure. Proses pemaknaan dikaji lebih jauh pada konsep denotatif dan konotatif. Pemaknaan merupakan proses hubungan antara penanda (signifier) dan petanda (signified) yang menghasilkan suatu makna konotasi. Konotasi yakni proses penyelusupan atau pelapisan makna kedua ke atas pesan fotografis atau fisik (Barthes, Terj., Hartono, 2010: 6). Signifikasi tataran pertama atau denotatif seringkali diasosiasikan sebagai ketertutupan makna, sensor, atau represi politis. Sedangkan signifikasi kedua atau konotatif menurut Barthes identik dengan operasi ideologi atau yang disebut dengan mitos yang berfungsi memberikan pembenaran bagi nilai-nilai yang dominan dalam periode tertentu. Dalam mitos juga terdapat pola tiga dimensi penanda, petanda dan tanda, namun sebagai suatu sistem yang unik, mitos dibangun oleh suatu rantai pemaknaan yang telah ada sebelumnya atau dengan kata lain, mitos adalah juga suatu sistem pemaknaan tataran kedua (Sobur, 2009: 71). Mitos sebagai kelanjutan dari sejarah tentu memiliki konsep yang bisa berubah, berdisintegrasi, atau bahkan menghilang. Meskipun demikian, penafsiran terhadap mitos dapat pula terkonsep dengan kuat melalui neologisme atau kata baru. Konsep ini bersifat aktual dan tidak bersifat historis, dengan kata lain penafsiran ini telah dinamai dan didefinisikan dalam kamus (Barthes, Terj., Mahyuddin, 2007: 311). Penyempurnaan yang lebih dalam terhadap semiotika struktural Saussure membuat teori Barthes dianggap sebagai bagian dari semiotika Post-Struktural. 
Hubungan antar tanda, dapat dikatakan sepenuhnya tergantung pada bagaimana seseorang dalam kesadarannya memaknai secara bebas hingga pada tataran mitos. Aspek mendasar dari teori ini adalah pembedaan makna denotatif dan konotatifnya. Pada dasarnya, denotatif dipahami sebagai hal literal atau konvensional, sedangkan konotatif makna yang tersirat darinya. Makna menurut Fiske, tidak bersifat absolut, bukan konsep statis yang terbungkus rapi dalam pesan. Makna memerlukan proses aktif dalam memunculkan, menciptakan dan menegosiasi (Fiske, Terj., Dwiningtyas, 2012: 76 - 77).

\subsection{Penelitian Terdahulu}

Iklan Djarum 76 seri Jin secara konten selalu memperlihatkan sisi komedi dan kelucuan yang cukup dekat dengan kehidupan masyarakat seharihari. Nuansa kerakyatan terutama masyarakat Jawa yang tinggal di perkampungan dan perkotaan yang sangat kental sebagai ciri khas menjadikan iklan ini mudah diterima dan berakulturasi secara ideologis di tengah masyarakat. Akulturasi secara ideologis yang dimaksud adalah pola pikir masyarakat dalam melihat berbagai persoalan seperti antar sesama kelompok sosial, kepada cara pandang perempuan, dan kepada pejabat, penguasa serta wakil rakyat. Ideologi ini menjadi sebuah paradigma yang bersifat kritik sosial.

Sebagai referensi, bahkan diungkapkan dalam sebuah abstraksi tesis yang ditulis dan berjudul "Kritik Sosial Pada Iklan Rokok Djarum 76 Filter Versi Pemimpin Jujur" (Supramono, (2015). http://eprints.umm.ac.id/21489/, akses 13 Januari 2019). Penelitian tersebut mengungkapkan sebuah framing iklan yang menuturkan tentang kegelisahan-kegelisahan di masyarakat terhadap isu-isu sosial dan diwujudkan dalam bentuk kritik yang satire. Pada penelitian lain, fokus pengkajian adalah hubungan sajian iklan Djarum 76 terhadap representasi sosial orang Jawa. Hal tersebut ditulis dalam sebuah jurnal penelitian yang diterbitkan oleh Jurusan Ilmu Komunikasi, Fakultas Ilmu Sosial dan Politik, Universitas Diponegoro, Semarang dengan judul "Representasi Orang Jawa Dalam Iklan Djarum 76" yang ditulis oleh Pertiwi dkk(https://ejournal3.undip.ac.id/index.php/interak si-online/article/view/4386, akses 13 Januari 2019). Meskipun kesimpulan dari penelitian tersebut justru menunjukkan bahwa iklan meninggalkan tatanan luhur (high culture) dalam idealisme Jawa (demitologi), namun hal tersebut justru menjadi point of view dari komedi iklan.

\section{METODE PENELITIAN}

\subsection{Jenis dan Sumber data}

Jenis penelitian ini adalah kualitatif deskriptif sebagai salah satu karakter dari penelitian kualitatif itu sendiri. Dalam penelitian deskriptif, sumber data yang dikumpulkan bisa berasal dari wawancara, catatan lapangan, foto, video, dokumen-dokumen, maupun memo. Penyajian data merupakan laporan hasil analisis yang melalui penelaahan satu demi satu (Moleong, 2011: 11). Sumber data pendukung penelitian adalah berbagai literatur dari berbagai sumber, baik sumber offline maupun online.

\subsection{Objek Penelitian dan Sampel}

Objek penelitian merupakan sumber data primer, yaitu kumpulan video-video iklan TVC Djarum 76, khususnya yang bertemakan Jin Jawa. Teknik sampling atau penggunaan sampel dalam penelitian kualitatif diperlukan untuk tujuan akurasi, efisiensi, dan efektifitas penelitian. Melalui sampel, akan didapatkan penelitian yang lebih mendalam terhadap suatu objek. Sampel dalam penelitian ini adalah beberapa video iklan TVC Djarum 76 yang pernah disiarkan di televisi dan diunggah oleh beberapa kanal Youtube, sejak 2009 - 2019. Melihat pola dan corak yang sama sejak iklan pertama ditayangkan, maka pemilihan sampel dilakukan secara random.

\subsection{Teknik Analisis}

Penelitian yang dilakukan adalah dengan melihat berbagai tanda besar yang menonjol dan sering tampak sebagai ciri khas dari iklan djarum 76 seri Jin. Selain itu, sebagai referensi atau data pendukung yaitu berbagai literatur dari buku-buku, referensi internet, serta hasil penelitian-penelitian yang sudah ada sebelumnya.

Teknik penelitian yang akan dilakukan adalah dengan mengamati seluruh video iklan Djarum 76 seri Jin hingga beberapa kali. Setelah itu akan ditemukan benang merah dari seluruh iklan terkait strategi dan juga visualisasi. Tahap berikutnya, akan dianalisis berbagai benang merah sebagai garis besar penanda-penanda iklan tersebut menggunakan teori semiotika. Teori semiotika Roland Barthes dipilih sebagai pisau bedah untuk mengkaji signifikasi atau pemaknaan berbagai tanda yang dikomunikasikan oleh iklan. Setelah melalui tahapan analisis tersebut, tahap berikutnya adalah menemukan relevansi antara tampilan dan makna dengan pertunjukkan teater tradisional kethoprak. Selanjutnya, akan ditarik kesimpulan yang merupakan titik temu antara gaya atau konsep yang ditampilkan oleh pengiklan dengan positioning product dan segmentasi konsumen. 
Dinamika Sosial Budaya, Vol 21, No. 2, Desember 2019, pp 138-151

p-ISSN: 1410-9859\& e-ISSN: 2580-8524

http://journals.usm.ac.id/index.php/jdsb

\section{HASIL DAN PEMBAHASAN}

\section{Wajah Iklan Rokok Dalam Media Televisi}

Kata "iklan" tentunya sudah tidak asing lagi di telinga kita. Mendengar kata tersebut, akan terbesit pada sebuah cara menjual, memamerkan, menawarkan produk pada masyarakat agar tertarik untuk membeli produk melalui berbagai media. Iklan dan promosi ibarat sebuah bagian dari mata rantai setiap industri terutama industri besar. Tanpa iklan, cukup sulit suatu bisnis dapat berkembang di era persaingan bebas dan ruang kapitalisme seperti saat ini. Iklan kini menjadi bagian tak terpisahkan dari kehidupan kita sehari-hari, baik di jalan, angkutan umum, pasar, mall, toko, radio, televisi, hingga internet.

Berbicara tentang iklan tentu tidak terlepas dari langkah-langkah strategi pemasaran atau marketing. Dalam ilmu marketing dikenal sebuah teori baku dengan rumus A - I - D - A. AIDA bukan hanya digunakan dalam bidang marketing, namun juga digunakan dalam model ilmu komunikasi. Iklan televisi sebagai bagian dari lingkup komunikasi, tidak terlepas dari aspek teoritisnya. Dalam teori komunikasi, AIDA merupakan salah satu model komunikasi linear atau satu arah (one way direction).

Pentingnya konsep AIDA di dalam iklan sangat mempengaruhi efektivitas dari iklan tersebut. Iklan yang efektif dan diterima oleh masyarakat harus berpegang pada rumus AIDA. Agar prinsip tersebut dapat tercapai, maka poin pertama dalam AIDA yaitu attention, haruslah dapat dicapai terlebih dahulu. Attention merupakan ujung tombak yang paling efektif dalam iklan. Menurut Djamal (2011), Tahapan perhatian (attention) adalah langkah awal meyakinkan khalayak bahwa terdapat sesuatu yang menarik untuk diketahui dalam iklan. Seorang pemirsa iklan tentunya harus dibuat tertarik dengan visualisasi awal yang diperihatkan oleh iklan. Hal menarik yang dimunculkan di awal menjadi magnet bagi pemirsa iklan untuk melihat bagianbagian selanjutnya dalam iklan. Diperlukan sebuah konsep kreatif agar gagasan dalam iklan mampu menarik perhatian, dan dapat diterima seluruh kalangan.

Setelah perhatian terhadap iklan telah didapat, diperlukan upaya untuk mempertahankan perhatian pemirsa iklan melalui konten iklan yang tentunya juga menarik (interest). Tujuan pokok dari tahapan ini untuk menjelaskan bagaimana pesan dalam media berhubungan dengan khalayak sehingga, didapatkan bagaimana pikiran-pikiran yang dimunculkan oleh khalayak. Pemikiran tersebut berkaitan dengan apakah isi pesan dapat memecahkan masalah saya? Atau sejalan dengan kehidupan saya (desire).

Hasrat yang telah terpancing dari audiensi selanjutnya memunculkan reaksi berupa tindakan (action) untuk membeli (Djamal \& Fachruddin, 2011: 72). Pemirsa iklan yang telah "terbius" dengan tampilan iklan tentu saja merupakan pemirsa potensial yang besar kemungkinan menjadi konsumen. Untuk menuju pada tahap tersebut diperlukan cara efektif dan kreatif dalam penyampaian pesan iklan kepada pemirsa iklan. Pesan iklan yang efektif akan menghasilkan reaksi terbaik dari khalayak atau pemirsa terhadap produk yang diiklankan. Diperlukan pemikiran literal untuk menghadirkan ide-ide atau gagasan yang menarik dalam iklan. Proses ini mengeksplorasi hubungan-hubungan baru dengan memecahkan pola-pola mapan yang ada untuk mendapat gagasan baru (Lee \& Johnson, terj., Munandar dan Priatna, 2011: 173). Proses ini berusaha memodifikasi cara lama atau melepaskan pemikiran lama (out of the box) menjadi pemikiran baru yang lebih menarik tanpa keluar dari konteks tentang produk yang diiklankan. Proses ini merupakan proses yang paling banyak digunakan saat ini. Hal ini dikarenakan kehidupan dan pemahaman perspektif masyarakat dalam melihat suatu peristiwa cenderung dinamis, sehingga diperlukan cara-cara kreatif dan pemikiran lateral sebagai hal yang fundamental dalam berkarya.

Kemampuan teknologi televisi sebagai kendaraan bagi media iklan memiliki kelebihan dalam komunikasi satu arah (one way direction), sehingga dengan kelebihan tersebut produsen dan kreator iklan harus mengoptimalkan daya tarik iklannya agar dilihat oleh pemirsa iklan. Sebuah iklan televisi harus mengandung pesan-pesan yang dapat membangun citra produk atau branding kepada khalayak melalui kekuatan alur dan presentasi audio visualnya. Konstruksi branding adalah apa yang dapat dimaknai dari pesan pengiklan oleh pemirsa iklan baik secara tersurat maupun tersirat. Komunikasi dapat dikatakan sempurna ketika pesan yang ditransmisikan oleh pengiklan mampu dipahami dengan sama oleh pemirsa iklan. Pesan yang tersurat adalah pesan yang mudah dipahami melalui penggunaan tandatanda yang jelas dan tegas, hal ini adalah aturan dasar bagi iklan-iklan dengan product knowledge. Sedangkan bagi iklan rokok dan berbagai produk tembakau, memiliki perbedaan dalam hal penyampaian pesan. Pada umumnya iklan rokok akan berfokus untuk membentuk kedekatan 
personal, perspektif gender, persepsi, dan daya tarik publik (thematic). Di televisi, iklan rokok ditayangkan pada malam hari setelah waktu primetime $(18.00$ - $21.00 \mathrm{WIB})$, hal ini dilakukan agar mencegah anak-anak melihat iklan rokok tersebut. Dalam penayangannya pun, iklan rokok mengikuti peraturan yang telah ditetapkan Pemerintah tentang penayangan produk rokok dan tembakau yang tidak boleh menampilkan produk.

Sifatnya yang sophisticated tersebut membuat pengiklan harus memikirkan konsep yang tepat dan menarik untuk iklan rokok. Dalam kehidupan sehari-hari, untuk meningkatkan eksistensinya di tengah masyarakat iklan rokok kerap mensponsori berbagai kegiatan seperti musik, olahraga, bahkan program beasiswa Pendidikan. Untuk memahami hal tersebut, tentu memerlukan analisis dan pendekatan yang lebih kritis terhadap makna dan tujuan iklan. Setiap tampilan iklan beserta tindakan korporasinya akan mempengaruhi positioning dan segmentasi produk di masyarakat.

Product positioning merujuk pada berbagai

keputusan dan kegiatan yang dimaksud perusahaan untuk menciptakan konsep tetap dan

mempertahankannya dari para pesaing (Lee \& Johnson, terj., Munandar dan Priatna, 2011: 100).

Positioning didasarkan pada peta konsumen yang telah terbentuk berdasarkan perbedaan-perbedaan selera, ekonomi, politik, dan budaya. Perbedaan ini juga menimbulkan diversifikasi produk, sehingga menciptakan ciri khas yang berbeda dari tiap produk yang ada.

\section{Sejarah Rokok dan Kretek Djarum 76}

Dalam kehidupan sosio-kultural masyarakat Indonesia, rokok merupakan benda mati yang sangat dekat dengan kehidupan kaum pria. Rokok dan kretek menjadi sebuah simbol yang melegitimasi nilai kejantanan atau maskulinitas di masyarakat. Keadaan ini pun banyak diperkuat oleh visualisasi dalam pemasaran melalui banyak media terutama media iklan televisi atau TVC.

Sebagai produk tembakau, rokok dan kretek memiliki sejarah yang sangat panjang. Seringkali di antara orang awam mengidentikkan rokok dan kretek sebagai benda yang sama, padahal keduanya memiliki perbedaan yang cukup mencolok. Perbedaan tersebut antara lain; rokok memiliki filter atau busa penyaring di pangkal batang sedangkan kretek tidak. Selain itu, kretek memiliki komposisi cengkeh dan tembakau yang lebih banyak daripada rokok sehingga memiliki rasa yang lebih kuat. Meski demikian, cara penggunaan dari keduanya tidak memiliki perbedaan. Dari segi pangsa pasar, rokok jenis kretek sangat digemari kalangan menengah ke bawah terutama masyarakat pedesaan.

Sejarah rokok di dunia telah dimulai sejak ribuan tahun lalu oleh suku asli Amerika bagian tengah. Setelah invasi bangsa Eropa ke Benua Amerika, rokok kemudian menyebar ke seluruh dunia dan cukup populer terutama di Eropa saat perang dunia.

"When learning about cigarettes it is necessary to begin by understanding the origin of the tobacco plant, which can be traced back as far as 6000 B.C. in Central America. In fact, during World War I and World War II soldiers were even given rations of cigarettes. In 1964, however, the United States Surgeon General released a report that stated smoking caused men to develop lung cancer" (ecigarette reviewed, (n.d.). https://ecigarettereviewed.com/the-history-ofcigarettes/, akses 18 Februari 2019).

Sejarah Panjang rokok menunjukkan bahwa rokok telah menjadi bagian penting sebagai lifestyle atau gaya hidup yang melekat di masyarakat sipil, bangsawan, hingga kalangan tentara. Hal tersebut juga menunjukkan bahwa kegiatan merokok merupakan bagian dari identitas maskulinitas yang lekat dengan kaum pria di luar dampak kesehatan yang dibawanya.

Di Indonesia, sejarah kretek memiliki tempat yang tidak terpisahkan dengan kebudayaan di masyarakat. Sejarah kretek yang populer adalah kisah tentang $\mathrm{H}$. Djamhari yang diyakini sebagai penemu kretek pertama. Kejadian tersebut berlangsung di kota Kudus, Jawa Tengah, sekitar tahun 1870 - 1880. Pada waktu itu H. Djamhari menderita sakit di dadanya, kemudian ia mengoleskan minyak cengkeh dan merasa baikan. Melihat penemuan itu, ia langsung meningkatkan dengan mengunyah cengkeh. Ternyata hasil lebih baik dirasakannya. Merasakan hasil yang maksimal, ia pun merajang cengkeh hingga halus kemudian ditaburkannya pada tembakau yang ia gunakan untuk merokok. Sekali lagi, cengkeh yang dikombinasikan dalam tembakau tersebut, membuat penyakitnya sembuh. Selanjutnya, tembakau dilinting, dan dibungkus dengan kulit jagung (klobot). Tak lama kemudian, api menjalar di gulungan tembakau. kata 'Kretek' didapat dari bunyi gemeretak cengkeh yang timbul ketika rokok dibakar (Muhammad, (2016). Rokok Kretek Bermula dari Obat Sakit Dada H. Djamhari. (https://www.liputan6.com/news/read/2583353/rok ok-kretek-bermula-dari-obat-sakit-dada-hajidjamhari, akses 18 Februari 2019). Penemuan 
tersebut digemari masyarakat dan akhirnya menyebar luas ke kota-kota dan daerah lain. Berkat penemuan tersebut, hingga saat ini kota Kudus terkenal sebagai produsen kretek terbaik Indonesia, bahkan menjadi kota lahirnya pabrik rokok terbesar, PT Djarum Kudus Tbk.

Sebagai sebuah produk populer dan telah eksis selama puluhan tahun, tentu kretek Djarum 76 memiliki sejarah panjang untuk mendapatkan positioning dan segmentasi konsumen atas produk. Djarum 76 kretek memiliki kedekatan yang sangat erat dengan gaya hidup masyarakat Jawa khususnya. Hal ini dipengaruhi oleh faktor historis tentang sejarah kretek nusantara yang berasal dari kota Kudus.

"Upon introduction in 1976, Djarum 76 rapidly gained a loyal following throughout Java, Bali, Kalimantan and Sumatra, particularly East and Central Java and Bali. Today, these cigarettes are available in 12 and 16-stick packages as well as in Twin Pack form" (Djarum, (n.d.). https://www.djarum.com/brands/domesticbrands/djarum-76/, akses 3 Juli 2019).

Nama Djarum 76 diambil dari tahun kemunculannya yang diperkenalkan pada 1976. Produk ini lalu dengan cepat mendapat tempat di Jawa, Bali, Kalimantan dan Sumatra, khususnya di Timur dan Tengah pulau Jawa dan Bali. Saat ini produk rokok itu tersedia dalam kemasan isi 12 dan 16 batang per-bungkus.

PT Djarum Kudus Tbk sendiri didirikan di Kudus, Jawa Tengah oleh Oei Wei Gwan pada tahun 1950. Permohonan izin usaha pendirian perusahaan tersebut baru dapat pengesahan dari Pemerintah pada tanggal 21 April 1951. Sesuai dengan permohonan penggunaan merk yang ia daftarkan kepada Pemerintah, perusahaan Oei Wei Gwan kemudian memakai merk "Djarum" untuk rokok yang akan diproduksinya. Merk ini semula milik seorang pengusaha rokok Pribumi dari "N.V. Moeroep", karena perusahaan ini tidak aktif berproduksi lagi, oleh pemiliknya merk tersebut dijual kepada Oei Wei Gwan. Pusat perusahaan Oei Wei Gwan yang pertama sebagai tempat produksi dan administrasi beralamat di jalan Bitingan Bari no. 28 (sekarang jalan Ahmad Yani no. 28) Kudus, Jawa Tengah (Djarum Kudus, (2013). http://djarumkudus.blogspot.com, akses 5 Juli 2019).

Berdasarkan data-data sejarah maka dapat disimpulkan bahwa kretek Djarum 76 memiliki pangsa pasar terbesar di pulau Jawa dan Bali. Harga yang terjangkau membuatnya sangat digemari oleh masyarakat kelas menengah ke bawah. Berdasarkan sejarah, kita dapat melihat bahwa budaya $u d u d$ atau merokok bagi orang Jawa telah berlangsung sangat lama dan kretek adalah rokok khas Jawa selain klobot.

\section{Analisis Penyajian Iklan Djarum 76 Seri Jin Melalui Semiotika Roland Barthes}

Iklan rokok adalah iklan yang unik, karena ia berjalan di atas narasi dan Bahasa audio/visual yang sama sekali tak berhubungan dengan produk yang dijual. Strategi beriklan yang demikian merupakan keharusan bagi produsen dan kreator iklan rokok serta produk tembakau karena terbentur oleh regulasi-regulasi penyiaran. Sebagai sebuah produk yang lebih mengutamakan penjualan brand image dan eksistensi akan produknya, maka diperlukan metode khusus untuk dapat mengetahui pesan yang dikomunikasikan dalam upaya membentuk branding produknya kepada khalayak. Salah satu metode yang sering digunakan adalah melalui teori semiotika.

Semiotika secara sederhana merupakan cabang keilmuan filsafat yang mengkaji tentang makna-makna dari beragam tanda (teks) yang dapat diindera oleh manusia. Dalam hal memaknai sesuatu, secara umum kita dihadapkan pada berbagai penalaran. Berbagai penalaran tersebut yaitu berdasarkan fakta-fakta yang bersifat umum (induktif), pengambilan kesimpulan (deduktif), dan dugaan atau hipotesa (abduktif). Semiotika juga melihat bagaimana perjalanan tanda sejak "produksi" hingga "reproduksi" dengan mempertimbangkan berbagai kemungkinan yang melingkupi tanda-tanda tersebut.

Konsep tanda denotatif dan konotatif Saussure yang dikembangkan oleh Barthes dalam mitologi menjadi hal penting dalam konsep pemikiran poststrukturalisme. Bagi Barthes, suatu makna konotatif bisa juga menjadi makna denotatif, karena kecenderungan perkembangan pemahaman dan perkembangan budaya. Sebelum menjadi sebuah makna konotatif, makna denotatif juga terdiri atas penanda dan juga petanda. Pada saat yang bersamaan dapat pula tanda denotatif juga merupakan penanda konotatif. Sehingga dalam konsep Barthesian tanda konotatif tidak sekedar mempunyai makna tambahan tetapi mengandung kedua bagian tanda denotatif yang ada. Pada saat ini, denotatif dianggap kekosongan atau tanpa makna karena sesungguhnya kita telah berada pada dimensi pemikiran konotatif. Sebuah makna konotatif yang kokoh atau memiliki kedudukan kuat di masyarakat tertentu dianggap sebuah mitos, hal ini bahkan membuat mitos dianggap sebagai sesuatu yang lumrah, natural atau biasa. Bagi 
Dinamika Sosial Budaya, Vol 21, No. 2, Desember 2019, pp 138-151

p-ISSN: 1410-9859\& e-ISSN: 2580-8524

http://journals.usm.ac.id/index.php/jdsb

Barthes, konotatif masih bermuatan historis dan kultural sehingga tidak natural (Barthes, Terj., Hartono, 2010: 14).

Proses kreatifitas dalam pemaknaan tidak hanya dialami oleh pembaca (pemirsa) namun juga pembuat tanda (kreator iklan). Dari uraian tersebut jelas tanda dapat bersifat arbitrer serta dapat bersifat konvensional atau struktural, hal ini sangat tergantung pada kemampuan sang kreator dan pembaca tanda dengan latar belakang budaya, pengetahuan dan pengalaman emipirisnya.

Jika melihat iklan produk rokok dan kretek di televisi, umumnya selalu menggunakan pemeran pria sebagai tokoh utama sekaligus ikon terhadap produk-produknya. Akibatnya, konsep iklan-iklan tersebut cenderung merepresentasikan nilai-nilai maskulinitas konvensional melalui visualisasinya. Hal itu muncul karena pada dasarnya rokok dibuat dan dikonsumsi oleh kaum pria. Sedangkan mitos bagi kaum pria selalu dikaitkan dengan kekuatan, semangat, dan petualangan. Akibatnya hingga saat ini produsen masih cenderung memasukkan unsur ekstrim dalam iklan rokoknya. Beberapa contoh produk yang mengiklankan rokok dengan mengkolaborasikan citra ekstrim dan kejantanan adalah; gudang garam, bentoel, dan djarum super. Untuk produk djarum super, iklan tidak hanya menampilkan hal-hal ekstrim, tetapi juga memadukannya dengan event olahraga yang bersifat gembira, sehat, dan kuat. Hal tersebut tentu saja tampak paradoks jika melihat dampak buruk rokok bagi kesehatan.

Sebagai produk rokok kretek, Djarum 76 memberikan tampilan yang berbeda dengan

menampilkan iklan yang lucu dan menghibur. Konsep yang unik ini menjadikannya sangat ikonik dalam benak masyarakat. Untuk mengkajinya lebih jauh, maka kita harus melalui proses pengamatan berulang-ulang terhadap iklan dan menemukan tanda-tanda utama yang khas dari iklan Djarum 76. Sebagai bagian dari produk audio visual, maka iklan tidak terlepas dari unsur-unsur sinematik dan naratif.

Unsur sinematik merupakan aspek-aspek teknis dalam produksi film/ iklan televisi. Terdapat empat elemen pembentuknya, yakni, mise-enscene, sinematografi, editing, dan suara. Masingmasing elemen tersebut saling berinteraksi dan membentuk gaya sinematik utuh. Mise-en-scene adalah segala hal di depan kamera, seperti; setting, tata cahaya, kostum, make up, dan akting. Sinematografi adalah perlakuan kamera terhadap film dan objeknya. Editing meliputi perlakuan transisi antar gambar (shot). Kemudian suara adalah tentang segala hal yang dapat didengar (Pratista, 2008, 1-2). Jika sinematik adalah berbagai elemen teknis dalam produk audio visual, maka unsur naratif adalah aspek non-teknis, atau tentang berbagai hal yang menyangkut cerita, konflik, sebab-akibat, penokohan, dll.

Untuk mempertajam fokus penelitian, maka batasan-batasan pengamatan perlu ditentukan, yaitu dengan memfokuskan pengamatan pada berbagai tanda khusus yang dianggap sebagai ciri khas iklan Djarum 76 versi Jin Jawa. Beberapa tanda yang mencolok antara lain:

Tabel 1 Penyajian Tanda Dalam Iklan Djarum 76 Seri Jin

\begin{tabular}{|c|c|c|}
\hline NO & Tanda Dalam Iklan & $\begin{array}{l}\text { Penyajian Tanda Dalam Seluruh Iklan Djarum } 76 \text { versi Jin } \\
\text { Jawa }\end{array}$ \\
\hline $\mathbf{1}$ & Jingle & Nyanyian "tujuh enaaam...". \\
\hline 2 & Tagline & Kalimat penutup dari Jin; "yang penting heppii..”. \\
\hline 3 & Kostum & $\begin{array}{l}\text { Busana tradisional Jawa oleh Jin lalu kaos dan busana kasual oleh } \\
\text { rakyat jelata, serta pakaian formal oleh pejabat. }\end{array}$ \\
\hline 4 & Bahasa & $\begin{array}{l}\text { Campuran bahasa Jawa, dialek, dan bahasa sehari-hari masyarakat } \\
\text { pada umumnya }\end{array}$ \\
\hline 5 & Latar/ Setting & $\begin{array}{l}\text { Sawah, Perkampungan, Pantai, Sudut kota, di dalam gedung, } \\
\text { Rumah. }\end{array}$ \\
\hline 6 & Tokoh/Peran Dalam Iklan & Jin Jawa, masyarakat Sub-urban, perempuan, pejabat. \\
\hline 7 & Cerita/ Thematic Joke & Tentang persoalan hidup sehari-hari. \\
\hline
\end{tabular}

Tanda-tanda pokok tersebut dapat kita saksikan sangat dominan saat mengamati iklan Djarum 76 seri Jin secara berulang-ulang. Sebagai metodologi, penulis menggunakan kaidah kualitatif deskriptif dengan membaca dan menganalisis berbagai tanda besar atau pokok dalam iklan.
Proses analisis dan pemaknaan menggunakan pendekatan teoritis semiotika signifikasi. Dengan menggunakan semiotika Roland Barthes akan lebih mudah menemukan pesan-pesan yang tersurat dan tersirat, dalam pemaknaan denotasi dan konotasi. 
Dari hasil pengamatan, dihasilkan tujuh tanda pokok yang merupakan bagian penting elemen atau struktur yang khas dari iklan. Elemen-elemen tersebut antara lain jingle, tagline, kostum, bahasa, latar, tokoh dan cerita. Berbagai tanda tersebut saling bahu-membahu membangun daya tarik terhadap iklan. Daya tarik tersebut tentu saja dapat dirumuskan ke dalam rumus pemasaran atau AIDA. Sebagai proses semiosis atau pemaknaan yang terus menerus, maka sebuah tanda yang telah dikenali dan dapat diindera bisa disebut sebagai tanda denotatif, sedangkan maknanya adalah konotatif. Namun operasi ideologi, perkembangan bahasa, dan pengetahuan bisa mempengaruhi makna tanda tersebut ke dalam pemaknaan tataran berikutnya. Tataran lapis kedua membuat tanda konotatif di awal menjadi tanda denotatif sedangkan makna penyelusupnya merupakaan makna konotatif. Hal ini akan terus bergerak sebagai proses signifikasi yang terus menerus.

Jingle di bagian awal merupakan attention yang juga sekaligus memberikan makna konotatif karena mampu menarik perhatian para pemirsa iklan di bagian awal. Penyebabnya, Suara tersebut selalu tak ketinggalan diperdengarkan di seluruh iklan-iklan djarum 76. Sedangkan nyanyian "tujuh enaam..." dalam jingle merupakan denotasinya. Iklan yang telah dikenal luas sebagai iklan rokok yang unik tentu saja mudah menarik perhatian.

Selanjutnya, bagian tubuh dari iklan yang meliputi kostum, bahasa, latar, tokoh dan cerita memberikan sebuah daya tarik (interest) terhadap iklan. Daya tarik tersebut karena isi iklan menampilkan guyonan atau kelucuan-kelucuan yang sangat dekat dengan kehidupan masyarakat sehari-hari. Tahap mempertahankan daya tarik ini penting agar pemirsa iklan terbius untuk masuk lebih dalam menonton iklan yang merupakan perwakilan dari sebuah produk. Beberapa pakar periklanan berpendapat bahwa agar sebuah kampanye iklan menjadi efektif, maka harus mengandung gagasan besar yang menarik perhatian konsumen, mendapatkan reaksi, serta memisahkan produk yang diiklankan dengan produk lain (Lee \& Johnson, Terj., Munandar dan Priatna, 2011: 170 - 171). Konsep ini diperlukan agar substansi dalam iklan dapat segera dipahami khalayak dan tercapai secara penuh. Sebagai iklan yang telah dikenal luas (konvensi) dan memiliki image yang lucu di mata masyarakat, maka iklan Djarum 76 berdiri secara otonom sebagai sebuah tanda konotatif sebagai produk rokok kretek yang lucu, sedangkan tanda denotatifnya adalah elemenelemen yang terdapat di dalam iklan.
Tahapan penting berikutnya adalah desire, atau kemampuan iklan untuk menimbulkan hasrat dari penonton untuk membeli. Sebagai brand dengan nama besar, tentu tidak sulit bagi perusahaan sebesar PT. Djarum untuk menjual apapun varian produknya, namun iklan tetap diperlukan sebagai penegas posisinya di pasar produk tembakau. Iklan bagi perusahaan besar dengan produk yang telah lama dikenal adalah sebagai reminder atau pengingat bagi masyarakat, bahwa Djarum hingga saat ini masih sangat eksis dan tetap berinovasi. Setelah hasrat untuk membeli telah terbentuk di benak konsumen, maka tahap selanjutnya adalah action, yaitu tindakan untuk membeli yang dilakukan oleh pemirsa iklan yang mulai tertarik pada produk. Sebagai sebuah produk rokok tentu saja tidak bisa dikatakan akan berlaku demikian mengingat, bahasa iklan yang digunakan sama sekali tidak persuasif terhadap produk. Bagi iklan rokok, pembentukan citra produk dan eksistensi nama produknya di pikiran masyarakat adalah hal yang utama. Maka dari itu, kebanyakan iklan rokok di televisi hanya dikuasai oleh brandbrand besar.

Jika diperhatikan, lima tanda pokok dalam iklan berdasarkan; kostum, bahasa, tokoh, latar, dan cerita menggambarkan ciri yang sangat dekat dengan kehidupan masyarakat sehari-hari di kalangan masyarakat sub-urban perkotaan dan pedesaan khususnya di Jawa. Kemunculan Jin Jawa (Totos Rasiti) dengan pakaian adat Jawa berupa topi blangkon dan baju beskap menjadi tokoh sentral yang memiliki kontras dengan pemeran lain. Sebagai Jin, ia memiliki kesaktian yang membuatnya bebas melakukan apapun. Namun, dengan tingkahnya yang kocak ia sering membuat jengkel tokoh-tokoh lain dalam cerita. Kehadiran Jin sebagai bagian dari imajinasi dan takhayul populer masyarakat menjadikan iklan Djarum 76 terasa unik dan segar. Keunikan terutama ditandai oleh adanya pencampuran antara kisah takhayul dengan kisah-kisah realita dan tokoh alam Ghaib yang berinteraksi langsung dengan tokoh-tokoh alam nyata.

Kelucuan sering muncul dari bentuk keganjilan terhadap hal-hal yang wajar atau distorsi dari keadaan normal di masyarakat. Dari berbagai penelitian tentang iklan Djarum 76, terlihat bahwa pokok utama iklan adalah menyajikan kritik sosial dan komedi yang sangat dekat dengan kehidupan masyarakat terutama di Jawa, sebagai cara menarik perhatian publik. Pokok-pokok tersebut merupakan tanda-tanda yang menghubungkan sekaligus menjadi kesimpulan awal bahwa visual iklan banyak menggunakan 
kaidah-kaidah seni pertunjukkan kethoprak. Untuk memastikan lebih jauh maka perlu kajian yang lebih mendalam untuk menemukan konotasi dan mitos tanda-tanda dalam pemaknaan wacana yang lebih luas.

\section{Seni Pertunjukkan Kethoprak Dalam Tayangan Iklan Djarum 76}

Dari pengamatan terhadap beberapa tanda besar dalam iklan, kita memperoleh kesimpulan bahwa iklan menyajikan konsep-konsep yang lucu dan nyeleneh dalam penyajiannya. Meski demikian dari berbagai tulisan mengenai konten iklan televisi Djarum 76 didapatkan sebuah pokok tema, yaitu menghadirkan sebuah kritik sosial dalam setiap sub-tema atau judul tayangannya. Kritik sosial yang diangkat selalu disajikan dengan cara yang menghibur, santai, dan mudah dimengerti oleh berbagai lapisan masyarakat.

Sepintas, visualisasi-visualisasi yang dibawakan oleh iklan sangat erat dengan budaya Jawa terutama melalui visualisasi sang Jin, akan tetapi hal tersebut seolah terdekonstruksi oleh kekonyolan dan sikap nyeleneh yang dibangun terhadap teks iklan. Budaya Jawa yang bersifat adiluhung, menjunjung tinggi norma-norma dan adat seolah terdegradasi oleh kekonyolan dan kelucuan yang dilakukan oleh Jin. Suku Jawa merupakan salah satu suku terbesar di Indonesia dan cukup mudah membaur di manapun. Dari sekian banyak suku etnis di Indonesia, Suku Jawa paling nyaman dalam berinteraksi. Karena, mereka terkenal santun. Dan sangat menghargai setiap orang. Kadang kala, saking santunnya, ketika terjadi sesuatu yang tidak disukai, mereka masih tersenyum. Jadi agak susah, menyelami pikiran orang dari suku Jawa (Ariko, (2019). https://jateng.garudacitizen.com/karakter-khasorang-jawa-tengah/, akses 12 September 2019). Maka, untuk memahaminya diperlukan pemikiran dikotomis yang mampu membedakan antara value budaya Jawa konvensional yang bersifat serius seperti dalam pertunjukkan wayang orang dan wayang kulit (purwa), dengan dagelan atau humor yang bersifat menghibur seperti dalam pertunjukkan kethoprak dan ludruk. Kebudayaan Jawa merupakan kebudayaan yang melekat atau mengikat terhadap masyarakat Jawa sebagai pembawa sifat-sifat keberadaban suku Jawa. Untuk memahami lebih jauh, maka terlebih dahulu kita harus mengerti apa itu seni pertunjukkan kethoprak.

Kethoprak merupakan salah satu jenis seni pertunjukan tradisional rakyat atau daerah di Jawa Tengah dan Yogyakarta yang masih potensial untuk direaktualisasi, restrukturisasi dan refungsialisasi pada saat sekarang. Kethoprak yang sifatnya lebih luwes dan dinamis dari seni pertunjukan lain sangat memungkinkan untuk itu. terdapat berbagai periodesasi dalam perkembangan kesenian kethoprak. Periodesasi tersebut merujuk pada perjalanan kethoprak dari yang awalnya hanya pertunjukkan rakyat yang sangat sederhana hingga populer di berbagai kalangan masyarakat dan mengalami modernisasi.

Kethoprak merupakan kesenian pertunjukan yang lahir di masyarakat dan diyakini telah ada sejak akhir abad ke - 18 di Surakarta dan diperkenalkan kepada kalangan keraton oleh Raden Mas Tumenggung Wreksodiningrat (Waluyo dalam Rohmadi \& Hartono, 2011: 97-98). Pertunjukan rakyat ini dapat dimainkan oleh semua kalangan baik pria maupun wanita, di samping memiliki gabungan unsur-unsur tari, suara, musik, sastra, drama, dan lain-lain. Akan tetapi secara keseluruhan unsur pokok berupa drama adalah yang paling menonjol. Nama kethoprak sendiri diambil dari bunyi yang dihasilkan dari alat musiknya. Pada waktu itu kethoprak menggunakan alat musik lesung (alat untuk menumbuk padi), suling, terbang, kendang. Irama yang dihasilkan, dung dung prak, prak, pating ketuprak (bahasa Jawa) sehinga orang menyebutnya kethoprak. Bunyi lesung ini biasanya juga diiringi oleh nyanyian-nyanyian. Dari bunyi-bunyian ritmis yang khas inilah kemudian lahir kesenian kethoprak (Putra, (2013). http://sejarahdalamdunia.blogspot.com/2013/08/sej arah-kethoprak.html, akses 11 September 2019). Dalam perkembangannya, peralatan musik ditambah dengan menggunakan kendang dan seruling, serta dibubuhi oleh berbagai cerita pendek baik seputar kehidupan sehari-hari maupun legenda di sekitar tempat pertunjukan.

Kethoprak lebih banyak menceritakan tentang keseharian masyarakat Jawa pedesaan ketika itu yang bercorak pertanian, nelayan, atau pedagang. Kethoprak menggunakan kostum sederhana, cara penampilannya disertai tarian yang berlebihan dan lucu hingga penonton menyebutnya dengan tontonan badutan (banyolan/ lawakan) yang segar (Waluyo dalam Rohmadi \& Hartono, 2011: 99). Dalam perkembangannya, seni kethoprak mengalami penganekaragaman cerita dan mulai mengangkat kisah-kisah pewayangan, kerajaan, mitos dan legenda. Keanekaragaman dimungkinkan karena sifat kesenian kethoprak yang luwes, akan tetapi komedi atau dagelan merupakan hal yang paling menonjol dalam seni teater rakyat tradisi seperti kethoprak. 
Kethoprak sebagai seni teater tradisional dianggap memiliki persamaan dengan teater modern seperti sinetron dan film. Keduanya samasama membutuhkan dalang atau sutradara yang mengatur cerita dan pengadeganan. Perbedaan yang hadir antara teater tradisional dan modern antara lain penyutradaraan, panggung, dan interaksi. Dalam teater tradisional terutama teater rakyat, sutradara (dalang) hanya mengarahkan lakon yang dimainkan sementara naskah tidak ada atau bersifat improvisatoris. Dalam kethoprak misalnya, dalang hanya menyampaikan tema, judul, dan naskah secara lisan, selanjutnya sepenuhnya pertunjukkan ada di tangan pemain (Damono, 2012: 39). Hal yang berbeda terdapat pada teater modern yang mengharuskan adegan sesuai naskah dan memperkecil improvisasi, sehingga peran sutradara sangat vital. Naskah dalam drama modern digunakan untuk memudahkan director atau pro director dalam mengatur pengadeganan dan pengambilan gambar terutama dalam sistem multicam (Damono, 2012: 43). Panggung yang disajikan pada teater modern lebih tertata dengan peralatan yang sangat kompleks. Dalam hal interaksi dengan penonton, teater tradisional menganggap penonton sebagai bagian dari pertunjukannya, berbeda dengan teater modern yang sangat berfokus pada cerita sehingga sangat minim interaksi.

Sebagai pertunjukkan tradisional Jawa, kethoprak dianggap membawakan sosiologisme humor khas Jawa. Kekhasan itu antara lain ditunjukkan melalui lakon, bahasa, dialek, dan bentuk candaan yang pada umumnya bersifat kritis terhadap berbagai persoalan sosial yang dekat dengan kehidupan sehari-hari. Humor secara umum mengangkat hal-hal lain di balik realitas kehidupan sehari-hari. Humor adalah menghadirkan keganjilan-keganjilan dari realitas, seperti yang dikemukakan Schopenhauer, setiap orang akan memiliki 'realitas' terhadap suatu hal, dan apabila kita diberikan keganjilan dengan membelokkan 'realitas' tersebut, maka kita akan tertawa (Kresnoadi, (2013). http://www.keribakeribo.com/2013/12/humor-dan-relasi-

implementasi-terhadap.html, akses 18 Juni 2019) Penyampaian pesan dari para pemain yang berimprovisasi membuatnya lebih mudah dipahami dan mudah diterima oleh banyak lapisan masyarakat terutama kelas menengah ke bawah.

Meski demikian baik kethoprak maupun ludruk merupakan pertunjukkan yang memanfaatkan 'kebalikan' atau 'keganjilan' dari nilai-nilai budaya Jawa yang dianggap serius dan tinggi. Karakter masyarakat Jawa yang santai tidak terpisahkan dari adanya guyonan-guyonan serta dagelan yang menghibur dalam kesehariannya. Hal tersebut membuat pertunjukkan-pertunjukkan yang menghadirkan dagelan Jawa juga tak lepas dari budaya masyarakat Jawa itu sendiri.

Iklan Djarum 76 dalam dialognya, banyak menggunakan bahasa Jawa yang bercampur dengan bahasa Indonesia atau dialek masyarakat umum sehari-hari. Seiring perkembangan zaman dan teknologi informasi, terjadi perubahan pada bahasa Jawa. Dalam pergaulan sehari-hari masyarakat Jawa, seringkali terjadi dwibahasa atau percampuran dengan bahasa Indonesia ataupun lainnya. Menurut Rohmadi (2011), masyarakat penutur bahasa Jawa merupakan masyarakat dwibahasa yang tersebar di Jawa Tengah, Timur, dan Yogyakarta (DIY). Hal ini merupakan fenomena pemakaian bahasa dan dipengaruhi penguasaannya terhadap bahasa Jawa dan bahasa lainnya (Rohmadi \& Hartono, 2011: 177). Hal ini juga dipengaruhi oleh modernisasi budaya sehingga berimplikasi pada penggunaan bahasa. Seringkali dalam pergaulan terutama anak muda di Jawa mencampurkan bahasa Jawa dengan bahasa lainnya sehingga timbul bahasa baru. Pencampuran tersebut menjadi faktor yang membagi antara bahasa Jawa kromo inggil dan bahasa ngoko. Pada bahasa ngoko, lebih bersifat terbuka dan dinamis dengan pengaruh (interferensi) budaya dari luar. Hal ini dikarenakan sifat dan penggunaan bahasa tersebut sebagai bahasa pergaulan antara teman, kerabat, atau pada yang lebih muda. Keberagaman bahasa Jawa juga dipengaruhi faktor letak geografis penggunanya. Secara garis besar, di kalangan masyarakat Jawa dikenal pembagian berdasarkan dialek dan logatnya seperti pada bahasa ngapak dan bandek atau keratonan. Penggunaan bahasa Jawa yang sederhana dan bercampur dengan bahasa Indonesia membuat iklan Djarum 76 lebih mudah dipahami dan disukai oleh lebih banyak lapisan dan kelompok masyarakat.

Selain bahasa, kostum yang digunakan juga memberikan keunikan tersendiri. Jin djarum 76 terlihat mengenakan pakaian adat Jawa berupa baju beskap, blangkon, dan kain jarik. Menurut masyarakat Jawa, pakaian tersebut merupakan pakaian adat kejawen. Pakaian tersebut umumnya sering digunakan oleh dalang, masyarakat keraton, atau pada saat upacara adat. Pada kain jarik dan blangkon yang dikenakan terdapat motif batik. Sejak zaman dahulu, masyarakat Jawa baik lakilaki maupun perempuan telah akrab dengan batik. Batik sering digunakan dalam berbagai acara tradisional hingga formal dan telah dikenal sejak 
ratusan tahun lamanya (Bayuadhy, 2015: 119). Maka, masyarakat Jawa sejak zaman kerajaan memang telah akrab dengan batik yang motifnya menggambarkan nilai-nilai dari falsafah hidup orang Jawa. Dalam sistem masyarakat Jawa klasik yang feodal, kegiatan membatik dilakukan oleh kaum perempuan. Bagi masyarakat Jawa, batik bukan hanya hanya digunakan untuk melatih keterampilan lukis dan sungging, tetapi juga penuh dengan pendidikan etika dan estetika bagi perempuan zaman dahulu. Motif batik terbilang sangat beragam dan terdapat maksud-maksud tertentu di balik simbol-simbolnya, sehingga dalam menentukan corak batik yang dikenakan harus disesuaikan dengan upacara yang akan dilakukan (Bayuadhy, 2015: 120-122). Penggunaan kain batik secara simbolik pada sosok Jin mengindikasikan sebuah upaya yang dilakukan pengiklan dalam rangka menyuarakan kepada publik bahwa produknya memiliki relasi yang kuat dengan budaya Jawa.

Teater tradisional rakyat selalu erat dengan tampilan yang lucu dan menghibur sehingga keberadaannya sempat populer di tengah masyarakat. Teater tradisional rakyat berasal dan tumbuh dari rakyat sehingga sudah tentu berbeda dengan pertunjukkan wayang yang tumbuh di kerajaan dan bersifat serius serta feodalistik.

Selain keunikan dari budaya Jawa yang diangkat, hal menarik dari konten iklan adalah adanya beberapa konflik antara Jin dan manusia, serta Jin dan Jin. Konflik dipicu melalui karakter Jin yang lucu, semaunya sendiri, santai, suka menolong, namun juga suka meremehkan. Beberapa diantaranya merupakan sifat yang positif, namun terdapat juga sifat negatif. Jika dilihat secara parsial atau sebagian sudut pandang memang Jin telah merusak nilai-nilai asli budaya Jawa. Akan tetapi, penulis melihat hal tersebut merupakan strategi pengiklan agar iklan terlihat menarik. Dari penyimpangan tersebut timbul sebuah konflik dengan tokoh lain dalam iklan. Konflik membangun cerita dan emosi, kemudian hal yang menyimpang dan berlebihan sering dipahami sebagai bagian dari komedi. Jika dilihat pada masing-masing iklan, tampak Jin seolah-olah menjadi eksekutor yang menghukum tokoh-tokoh lain yang dianggap membawa patologi sosial. Jin Jawa sebagai tokoh utama, secara hakikat hampir tidak memiliki batasan dibandingkan dengan tokoh lainnya dalam iklan.

Di antara konflik Jin dan manusia, terdapat beberapa sub - konflik yang terbagi dalam beberapa tema iklan. Konflik-konflik tersebut antara lain adalah; konflik dengan rakyat kecil, remaja, para pejabat, dan perempuan. Secara keseluruhan, konflik-konflik tersebut ditampilkan melalui kelucuan dan kekonyolan. Sebagai contoh, konflik pada iklan-iklan yang menggambarkan hubungan antara rakyat kecil dan Jin. Digambarkan oleh iklan, rakyat kecil seperti disepelekan oleh Jin dan berakhir "apes" saat meminta tolong pada Jin. Beberapa contoh visual di dalam iklan, rakyat kecil digambarkan memiliki wajah pas-pasan, polos, lugu, berpendidikan rendah, dan penghayal atau pemimpi. Gambarangambaran tersebut dapat disaksikan pada iklan versi "Mawar kembang Desa", "jangkrik", "pengin sugih pengin ganteng", dan "kepingin eksis".

Dari pengamatan dan analisis yang dilakukan, iklan Djarum 76 merupakan iklan rokok yang revolusioner karena menggunakan pendekatan humor atau guyonan dalam penyajiannya. Guyonan yang disampaikan dari setiap judulnya mengandung kritik sosial terhadap fenomenafemona di masyarakat. Kritik sosial yang disampaikan merupakan kritik terhadap berbagai persoalan masyarakat yang dianggap menyimpang dari nilai-nilai filosofis masyarakat Jawa. Kehadiran Jin sebagai ikon produk, sebenarnya juga bisa dianggap sebagai kritik, terutama bagi sebagian masyarakat kita yang masih mempercayai mitos-mitos klenik dan terkadang memohon pada Jin sebagai upaya jalan pintas. Alih-alih mendapatkan kesuksesan, yang terjadi justru penyesalan karena telah meminta kepada selain Allah SWT. Hal ini menjadi sebuah point of view atau center point dari humor yang disajikan.

Unsur lain yang tidak lepas dari pertunjukkan kethoprak adalah kehadiran suara musik gamelan. Pada tampilan iklan Djarum 76 seri Jin, nuansa musik gamelan terasa sangat kental meskipun terjadi pencampuran dengan musik modern dan atmosfer suasana setting adegan. Adanya pencampuran tersebut menandakan bahwa iklan menghadirkan sebuah konsep pagelaran atau pertunjukkan kethoprak modern. Meski demikian, berbagai kaidah-kaidah pertunjukkan kethoprak tradisional masih sangat mendominasi terutama dari tampilan visual, konten cerita dan humornya. Maka, berdasarkan temuan-temuan tersebut, iklan Djarum 76 dapat disimpulkan sebagai salah satu bentuk pertunjukkan kethoprak modern. Hal tersebut juga didasarkan pada sifat pertunjukkan kethoprak yang fleksibel dan terbuka dengan berbagai perubahan serta inovasi kekinian. 
Dinamika Sosial Budaya, Vol 21, No. 2, Desember 2019, pp 138-151

p-ISSN: 1410-9859\& e-ISSN: 2580-8524

http://journals.usm.ac.id/index.php/jdsb

\section{KESIMPULAN}

\section{Kesimpulan}

Di tengah persaingan industri rokok yang cukup sengit dari sisi marketing, dewasa ini turut melibatkan persaingan berbagai industri periklanan. Persaingan tidak lagi dipandang dari sisi kualitas dan kuantitas, namun juga tentang strategi menarik perhatian masyarakat akan produknya. Iklan sebagai sebuah media pemasaran menjadi jalan masuk bagi berbagai produk-produk industri baik kecil hingga besar ke dalam lingkungan masyarakat. Iklan dalam bentuk selebaran brosur, pamflet, radio, hingga televisi telah lama menjadi pilihan bagi para produsen khususnya produk rokok.

Djarum 76 sebagai salah satu varian dari perusahaan rokok besar Indonesia PT Djarum, dewasa ini menggunakan corak iklan yang unik dan berbeda dengan produk rokok lain. Iklan rokok mau tidak mau menggunakan strategi beriklan yang tidak langsung menunjukkan produknya karena terikat pada rambu-rambu aturan penyiaran. Iklan yang hanya menampilkan hiburan dan kelucuan dari djarum 76 menghadirkan pertanyaan-pertanyaan tentang bagaimana strategi dan wacana yang dibangun di balik pemaknaanpemaknaan terhadap visualisasi tersebut. Mengingat iklan rokok merupakan salah satu iklan ber-budget besar, tentu produsen tidak hanya ingin menampilkan hiburan tanpa adanya imbal balik berupa daya tarik terhadap produk yang dijual.

Dari penelitian ini dapat ditarik kesimpulan bahwa salah satu strategi beriklan produk kretek Djarum 76 adalah dengan memanfaatkan konsepkonsep yang telah tumbuh di dalam hiburan rakyat. Sebagaimana terlihat dalam iklan tersebut, banyak menggunakan kaidah-kaidah seni pertunjukkan rakyat berupa kethoprak. Iklan yang menghibur ini menjadi inti strategi branding yang dilakukan pengiklan dan tetap mentautkannya dengan konsep yang lucu, unik, tradisional, serta merakyat sehingga memunculkan image sebagai produk yang terjangkau untuk kalangan menengah ke bawah. Djarum, sebagai sebuah brand dari produkproduk rokok yang sudah terkenal sejak lama menjadikannya memiliki tempat dan telah terpercaya bagi masyarakat.

\section{Saran}

Melalui penelitian ini, telah membuka berbagai ruang diskusi mengenai iklan-iklan rokok. Diskusi dapat dilanjutkan oleh penelitian lain pada studi fenomenologi mengenai kompetisi-kompetisi yang terjadi antar perusahaan rokok. Kompetisi tersebut antara lain dapat terlihat pada cara

menarik perhatian calon konsumen dan cara mempertahankan eksistensinya melalui iklan televisi. Masing-masing produsen menghadirkan keunikan tersendiri dari iklan-iklannya, hal ini sangat menarik untuk dibedah dan dianalisis untuk memperkaya studi mengenai pemasaran dan branding. Selain itu, menarik untuk melihat lebih lanjut persoalan atas dampak dari iklan-iklan yang semakin kompetitif terhadap pembentukan selera dan lifestyle di masyarakat.

\section{DAFTAR PUSTAKA}

Barthes, Roland. (2010). Imaji, Musik, Teks (Analisis Semiologi Atas Fotografi, Iklan, Film, Musik, Alkitab, Penulisan dan Pembacaan Serta Kritik Sastra), Terj. Agustinus Hartono. Yogyakarta: Jalasutra.

Barthes, Roland. (2007). Membedah Mitos-Mitos Budaya Massa: Semiotika atau Sosiologi Tanda, Simbol, dan Representasi. Terj. Ikramullah Mahyuddin. Yogyakarta: Jalasutra.

Bayuadhy, Gesta. Tradisi-Tradisi Adiluhung Para Leluhur Jawa (Melestarikan Berbagai Tradisi Jawa Penuh Makna), Yogyakata: Dipta, 2015.

Budiman, Kris. (2011). Semiotika Visual: Konsep, Isu, dan Problem Ikonositas, Yogyakarta: Jalasutra.

Damono, Sapardi Djoko. Alih Wahana: Editum, 2012.

Djamal, Hidajanto \& Andi Fachruddin. (2011). Dasar-Dasar Penyiaran (Sejarah, Organisasi, dan Regulasi), Jakarta: Kencana.

Fiske, John. (2012). Pengantar Ilmu Komunikasi, Terj. Hapsari Dwiningtyas. Jakarta: Rajagrafindo Persada.

Hoed, H. Benny. (2001). Dari Logika Tuyul ke Erotisme, Jakarta: Yayasan Indonesiatera.

Lee, Monle \& Carla Johnson. (2011). PrinsipPrinsip Periklanan Dalam Perspektif Global, Terj. Haris Munandar, Dudi Priatna. Jakarta: Kencana.

Moleong, L.J. (2011). Metodologi Penelitian Kualitatif Edisi Revisi. Bandung: PT. Remaja Rosdakarya. 
Dinamika Sosial Budaya, Vol 21, No. 2, Desember 2019, pp 138-151

p-ISSN: 1410-9859\& e-ISSN: 2580-8524

http://journals.usm.ac.id/index.php/jdsb

Piliang, Yasraf Amir. (2009). Posrealitas (realitas Kebudayaan Dalam Era Posmetafisika), Yogyakarta \& Bandung: Jalasutra.

Pratista, Himawan. (2008). Memahami Film, Yogyakarta: Homerian Pustaka.

Putra, Yoga Rarasto. (2016). Pemaknaan Coding Dalam Iklan Djarum 76 Seri Jin. Tesis tidak diterbitkan, Jakarta: Sekolah Pascasarjana IKJ.

Sobur, Alex. (2009). Semiotika Komunikasi, Bandung: PT Remaja Rosdakarya.

Sudjiman, Panuti \& Aart Van Zoest. (1992). Serba-Serbi Semiotika, Jakarta: Gramedia.

Supriyanto, Sugeng. (2008). Meraih Untung Dari Spanduk Hingga Billboard, Yogyakarta: Pusaka Grahatama.

Rohmadi, Muhammad \& Lili Hartono. Kajian Bahasa, Sastra, dan Budaya Jawa: Teori dan Pembelajarannya, Surakarta: Pelangi Press \& JPBS FKIP UNS, 2011.

Ariko, Dedi. (2019). Karakter Khas Orang Jawa Tengah, "Nrimo Ing Pandum". https://jateng.garudacitizen.com/karakter-khasorang-jawa-tengah/, (akses 12 September 2019).

DH, Kresnoadi. (2013). Humor dan Relasi Implementasi Terhadap Komedi. http://www.keriba-keribo.com/2013/12/humordan-relasi-implementasi-terhadap.html, (akses 18 Juni 2019).

Djarum Kretek. (2013). Djarum Kudus. http://djarumkudus.blogspot.com, (akses 5 Juli 2019).

Djarum. (n.d.). Brands. https://www.djarum.com/brands/domesticbrands/djarum-76/, (akses 3 Juli 2019).

ecigarette reviewed. (n.d.). The History of Cigarettes. https://ecigarettereviewed.com/thehistory-of-cigarettes/, (akses 18 Februari 2019).

Komisi Penyiaran Indonesia. (2014). Edaran Untuk Lembaga Penyiaran Perihal Iklan Rokok. http://www.kpi.go.id/index.php/id/edaran-dansanksi/31912-edaran-untuk-lembaga-penyiaranperihal-iklan-

rokok?detail3=4184\&detail5=5366, (akses 15 Juli 2019).

Kuncara, Purba. (2012). Seberapa Efektifkah Iklan Anda? http://adabisnis.com/seberapaefektifkah-iklan-anda/, (akses 30 Agustus 2015).

Muhammad, Djibril. (2016). Rokok Kretek Bermula dari Obat Sakit Dada H. Djamhari. https://www.liputan6.com/news/read/2583353/r okok-kretek-bermula-dari-obat-sakit-dada-hajidjamhari, (akses 18 Februari 2019).

Putra, Febrian Eka. (2013). Sejarah Kethoprak. http://sejarahdalamdunia.blogspot.com/2013/08 /sejarah-kethoprak.html, (akses 11 September 2019).

Supramono, Anggi Dwi. (2015). Kritik Sosial Pada Iklan Rokok Djarum 76 Filter Versi

Pemimpin Jujur (Analisis Semiotik). http://eprints.umm.ac.id/21489/, (akses 13 Januari 2019), Malang: University of Muhammadiyah Malang. 